\title{
THE IMPACT OF RISK AND INFLATION ON RESIDENTIAL PROPERTY DEVELOPMENT DECISION
}

\author{
Udoka Israel Sunday \\ Department of Estate Management Akwa Ibom State Polytechnic, \\ Ikot Osurua, Akwa Ibom State, Nigeria \\ E-mail address: nkasiobisilasoguzor@yahoo.com
}

Keywords: Risk; Inflation; Residential property; Development; decision

\begin{abstract}
Residential property development decision most times come as a bit to quelling housing poverty, but at the same time a veritable source of income as well as a better bulwark against inflation and other risk than any other asset in isolation. However, this paper is written to assess the impact of risk and inflation on residential property development decision as the aim. Secondary data source was adopted as methodology for the research; while the result was that residential property development/investment provides significant favourable outcome than other property investments or businesses during inflationary/risky periods. It was therefore recommended that residential property investment/development should be involved in most investment portfolios at most times to mitigate risk of whatever type.
\end{abstract}

\section{INTRODUCTION}

The term risk refers to the likelihood of loss or less than expected returns from an investment. It is the chance that an investment's actual return will be different from the expected (www.investorword.com/4292/risk/html).

According to Professor I. U. Kalu, risk is a combination of internal and external factors which make return projections from investments liable to vary from the actual.

Risk includes the possibility of losing some or all of the original investment. Different version of risk is usually measured by calculating the standard deviation of the historical returns or average returns of a specific investment. A high standard deviation indicates a high degree of risk and viceversa. According to Brueggman, Fisher and Stone (1989), risk characteristic differentiate real estate investment from the other alternatives such as common stock, corporate bonds, and include:

a. Business Risk: Risk of loss due to fluctuations in economic activities, and its effect on the variability of income produced by the investment. The case of real estate, business risk would be factors that affect the net operating income and resale price of the property. Changes in economic conditions such as a recession may affect some properties more than others. Those affected to a greater degree than others would be riskier.

b. Financial Risk: Risk of loss due to the use of debt financing (referred to as financial leverage). Financial risk increases as the amount of debt on a real estate investment is increased. The risk depends on the extents of prior claims of lenders on income and proceeds upon liquidation of the investment.

c. Liquidity Risk: Occurs to the extent of the lack of a continuous market with many buyers and sellers, and frequent transactions. The more difficult an investment is to liquidate, the greater the risk that a price concession may have to be given to a buyer should the seller have to dispose of the investment quickly.

d. Purchasing Power Risk: Occurs to the extent that income from a security does not adjust to inflation, thereby reducing the real value of the underlying security. Certain types of business activity are more favourably or adversely affected by inflation than others. Hence, this is a source of risk that must be considered in an investment analysis. 
e. Management Risk: this type of risk is based on the capability of management and its ability to innovate, respond to competitive conditions and operate the business activity efficiently.

f. Interest Risk: Changes in interest rates will affect the price of all securities and investments. However, depending on the relative maturity (short-term versus long-term investment), some investment prices will respond more than others, thereby increasing the potential for loss and gain.

g. Legislative Risk: Comes about in the form of tax law changes, rents control, zoning, and other restrictions imposed by government that could adversely affect the profitability of investment.

Essentially, these risk characteristic are, in large part, the reasons for differences in returns between the alternative investments.

\section{INFLATION}

Inflation as an economic term originally referred to increases in the amount of money in circulation, and some economists use the word in this way. However, most economists today use the term to refer to a rise in the price level. An increase in the money supply is called monetary inflation; to distinguish it from rising prices, which may also for clarity be called "price inflation" (http://guidance.fedelity.com./viewpoints/inflation-vs-deflation).

Often economic concepts related to inflation include:

(a) Deflation - a fall in the general price level

(b) Disinflation - a decrease in the rate of inflation

(c) Hyperinflation - an out of control inflationary spiral

(d) Stagflation - a combination of inflation, slow economic growth and high unemployment

(e)Reflation - an attempt to raise the general level of prices to counteract deflationary pressures.

Core inflation is a measure of inflation for a subset of consumer prices which excludes food and energy prices which rise and fall more than other prices in the short term.However, inflation may also be used to describe a rising price level within a narrower sets of assets, goods or services within the economy such as commodities (including food, fuel, metals), tangible assets (such as real estate), financial assets (such as stocks, bonds) services (such as entertainment and healthcare), or labour.

\section{TYPES OF INFLATION}

Keynesian economics proposes that changes in money supply do not directly affect prices, and that visible inflation is the result of pressures in the economy expressing themselves in prices (http://guidance.fedelity.com./viewpoints/inflation-vs-deflation). There are three major types of inflation, as part of what Robert J. Gordon calls the "triangle model".

- Demand-Pull Inflation: This is caused by increases in aggregate demand due to increased private and government spending etc. Demand inflation encourages economic growth since the excess demand and favourable market conditions will stimulate investment and expansion.

- Cost-Push Inflation: This is also called "supply shock inflation".It is caused by a drop in aggregate supply (potential output). This may be due to natural disasters, or increased prices of inputs. For example, a sudden decrease in the supply of oil, leading to increased oil prices, can cause cost-push inflation. Producers for whom oil is a part of their costs could then pass this on the consumers in the form of increased prices. Another example stems, from unexpectedly high losses, either legitimate (catastrophes) or fraudulent (which might be particularly prevalent in times of recession).

- Built-in Inflation: This is induced by adaptive expectations, and is often linked to the "price/wage spiral". It involves worker trying to keep their customers as at higher prices, 
leading to a vicious circle. Built-in inflation reflects events in the past, and so might be seen as hangover inflation.

\section{INFLATION AS RISK}

Inflation is seen as the rise in price as a result of an increase in the supply of money; while risk is considered as the possibility of meeting loss. However, from the definitions, inflation as a situation can be considered as risk. It is a situation which might cause a loss or losses to investor, occasioned by abnormal increases in the prices of residential properties without proportionate increase in the supply of the commodity.

\section{THE IMPACT OF RISK AND INFLATION ON RESIDENTIAL PROPERTY DEVELOPMENT DECISION}

Real estate generally, and residential properties specifically appears to have the strongest correlation among assets to inflation. This real estate includes direct real estate and real estate investment trusts in residential properties. Both shows a position, consistent sensitivity to inflation is low, with both assets offering modest protection when inflation is low, to moderate and improved protection in high inflation environments. Of the two types of real estate assets, however, direct real estate, which includes residential properties exhibit more robust correlation across inflationary regimes. (https://vanguardinvestments.de/content/document/articles/insight/hedging-inflation.pdf, 2013). In contrast, real estate investment trusts performance is somewhat more similar to that of equities and its relationship to inflation changes depending on whether inflation is high or low. Real estate investment trusts turns negative when inflation is high and rising, but turns positive when inflation peaks and begins to decline. The similarity with equities is also apparent in real estate investment trusts response to the business cycle, which is more in line with developed equities than with direct real estate (residential property).

But like other assets, real estate brings its own unique risk factors to a portfolio. For one, it is highly correlated with the business cycle. As an economy moves into an expansionary phase, real estate tends to perform strongly as vacancies drop and landlords can more confidently raise rents. But a recessionary period may be a cause for concern. Illiquidity, especially for direct real estate, may be another concern. While direct real estate may help manage inflation risk in more environment than other assets classes, it may not, due to its illiquid nature be appropriate for all investors. In stressful economic times, liquidating the under-lying assets of direct real estate assets can be difficult even though returns may be sustainable. Therefore, the inclusion of direct real estate in a portfolio must be carefully ganged with respect to each investor's specific goals and liquidity needs.

\section{RISK/INFLATION AND DIRECT RESIDENTIAL PROPERTY INVESTMENT}

Real estate is often considered conceptually as a hedge against inflation. An approach to evaluating the relationship between investment and inflation that is fairly standard in the investment community (although less so in the academic literature) is to compute the contemporaneous correlation between inflation (example, change in consumer price inflation, available monthly) and asset returns at the same frequency. A correlation approaching $100 \%$ is considered sign of high sensitivity to inflation hedging properties.

There are three problems with this standard approach, as applied by investors and investment advisers - many of whom do not hedge but rather use strategic and tactical asset allocation to protect against inflation (Brad, Susan and Richard, 2011). First, the correlation coefficient gives equal weight to all historical periods without regard to whether inflation was high or low in those periods; whereas many investors seek inflation protection especially during periods of high inflation. Possible solutions to this problem includes computing a semi-correlation coefficient using data from only those months in which inflation was relatively high, or weighting each month according to the level of inflation during that month. Second, use of the contemporaneous correlation implies that only those assets, whose returns respond to inflation during the same month, 
are of value to investors as inflation protection. Returns of some assets, though, may be sensitive to inflation with a lag, mostly when inflation is unexpected. For example, even United States Treasury inflation protected securities (TIPS), which provide income explicitly linked to realized inflation through monthly adjustment to the bond principal, have a two to three month lag in their indexation to cost push inflation. Because of this reason, the investor's horizon remains a relevant empirical to insure in the study of risk/inflation sensitivity (Brad, Susan and Richard, 2011). Third, the correlation coefficient is a measure of co-movement, but not a measure of whether returns preserve purchasing power or provide what is termed an "effective" inflation hedge. This means, correlation measures whether asset returns move in the same direction as inflation, but to establish an effective inflation hedge one needs to use the correlation coefficient as an input, along with the volatilities of different asset returns to compute the appropriate hedge ratio. In practice, the stability of the correlation co-efficient is often the most challenging aspect in determining the optimal hedge ratio, and employing a hedge strategy. As an alternative to the optimal hedge ratio, the investor may consider other forms of inflation protection. One approach is to establish a strategic portfolio allocation with significant position in assets that preserve purchasing power during high inflation regimes, though a strategic allocation appropriate to high inflation regime may however produce poor return during low inflation regimes.

\section{RISK AND INFLATION SENSITIVITY TO DIFFERENT PROPERTY TYPES}

The value of income producing real estate in protecting against inflation and other risk arises from the adjustment process by which lease rents respond to changes in inflation. Different types of property are characterized by significant differences in lease provisions, and these give rise to differences in their risk and inflation sensitivity. The most important provision for risk and inflation sensitivity is the lease term and, consequently, the frequency of lease turnover and negotiation. At one extreme hotel (being a commercial property) have typical lease terms and only one, or a few nights, implying that rents can be adjusted almost continuously in response to changes in inflation as well as other risk.Residential properties typically employ 12 months lease, perhaps with monthly lease extensions after the first year implying that rent, can be adjusted annually, if not monthly. Warehouses typically have similarly short lease terms. For hotels and warehouses, the fact that lease rents are typically fixed during the entire duration of the contract term is mitigated by the fact that contract terms are typically short, potentially enabling properly owners to adjust rents in response to inflation. Other property types may employ automatic adjustments to changes in inflation, whether explicit or otherwise. For example, many retail leases specify monthly rented payments as a function of the sale revenues generated by each store; thus as inflation affects the sale prices of consumer goods, it affects lease rents as well (Lomelino, 2011).In some cases, especially with tenants that are government agencies, office lease may include an explicit adjustment in response to inflation; in these cases, office property returns may be sensitive to inflation even with long lease terms. A slightly different mechanism may affect lease rents for health care properties, including long term care facilities, if health care reimbursement rates are regulated, then inflation may be accounted for in determining payment for various health care services, and therefore pass through to owners of health care properties.

\section{METHOD AND PROCEDURE}

The data for this research came mainly from the secondary source. Textbooks, journals, magazines, as well as other publications from the internet formed the source that the ideas, arguments and concepts used in the research werebased.

\section{RESULT}

From the arguments above, it could be observed that residential property investments provide significant and comparably better outcomes which make them fair favourably more than other property types during inflation or any other risk periods. 


\section{CONCLUSION/RECOMMENDATION}

Residential property development decision analysed with risk and inflation provides the strongest protection as they are characterized by short duration bases or by rents linked to revenue. This therefore shows that residential properties provides a strong hedge against risk and inflation on conceptual grounds as it perform more than other risk/inflation sensitive assets, and has never exposed investors to significant directional inflation risk. However, based on empirical results, as well as theoretical arguments, residential properties offer the most attractive return characteristics, and deserve consideration in diversified risk and inflation protected portfolios.

Therefore as recommendation, it is suggested that residential property development/investment should be incorporated in most investment portfolios to mitigate risks of various categories and actually hedge inflation.

\section{References}

[1] Bond and Slezak (2010). The Optimal Portfolio weight for Real Estate with liquidity Risk and Uncertainty Aversion. http://ssrn.com/abstract=1691503.

[2] Brad Case, Susan M. Wachter and Richard B. Worley (2011) Inflation and Real Estate Investments. The Wharton School of the University of Pennsylvania.

[3] Bhardwaj, Hamitton and Ameriks (2011) "Hedging Inflation": The Role of Expectations. https:/vanguardinvestments.de/content/document/articles/insight/hedging-inflation.pdf.

[4] Lomelino, Gillet and Komarynaky (2011) "Inflation hedging with inflation Linked Bonds"

[5] Tower Watson. http://www.towerswatson.com/assets/pdf/4125/1101-TIPS-FIN.

[6] Markowitz "Portfolio selection" The Journal of Finance 7(1):77-91(1952) and portfolio selection: Efficient diversification of investments, New York: John Wiley and sons (1959).

[7] Prof. I. U. Kalu (2007) Property valuation and appraisal.Bon publications, Okigwe, Nigeria.

[8] Real Estate Economics (2007) 135 (3): 201-330.Ralls (2010): Bills Ralls, CFA “Inflation” or Deflation: prepare for either; FidelityInvestment. https://guidance.fidelity.com/viewpoints/inflation-vs-deflation.

[9] William B. Bruggeman, Jeffrey D. Fisher and Leo D. Stone (1989) Real Estate Finance. Irwin, Boston. 